
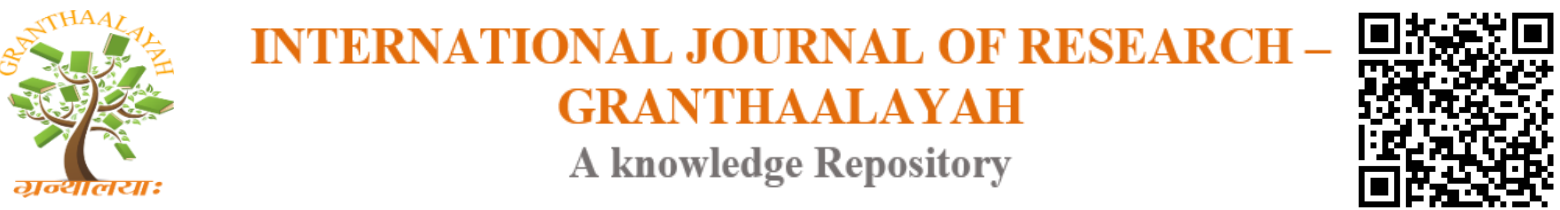

Science

\title{
THE RELATIONSHIP BETWEEN BEHAVIORAL OF HEALTH WITH THE USED OF PERSONAL PROTECTIVE EQUIPMENT (PPE) IN PT. SARANA AGRA GEMILANG KUPANG EAST NUSA TENGGARA
}

\author{
Landelinus Humau ${ }^{1}$, Hari Rarindo ${ }^{2}$, Andreas Umbu Roga ${ }^{3}$ \\ ${ }^{1,2,3}$ Graduate Health Sciences of Nusa Cendana University, Kupang, Indonesia
}

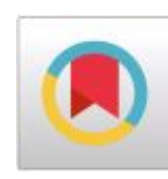

\begin{abstract}
Labor is human resources who have a very important role for the progress and development of an enterprise. Safeguards against labor was regulated in Law - Act as a regulation, which patent where involves safety of all the production and distribution of commodity and services. Based on the Results of some studies found that some accidents at workplace is due to human behavior who does not lead to his safety. Based on the results of the study some work accidents happened in PT. Sarana Agra Gemilang due to the workers who less their careful on their work that they did. The purpose of this research was to determine the relationship between behavior of health with the used of personal protective equipment (PPE) in PT. Sarana Agra GemilangKupang East Nusa Tenggara, 2017. This research is an analytic study with cross sectional study design is to know the relationship between the behavior with the use of PPE in PT. Sarana Agra GemilangKupang. The Population in this research was the workers at PT. Sarana Agra Gemilang the Population was 439 people. The researcher used random sampling method which each member / unit of the population has an equal opportunity to be samples, which obtained 99 workers as a sample. Analysis of the data in this research is descriptive, bivariate and univariate. The analysis in this research using Chi - Square is used to observe the influence and to determine the relationship between the respectively of independent variable and dependent variable with a value of $p<0,05$. The Consistent risk factors significantly influence the adherence was variable with values $(\mathrm{p}=0.005)$ The model probability or the extend of adherence is formed from the interaction of variables that affect of working period simultaneously with the value of $O R(O R=$ 0.053).
\end{abstract}

Keywords: Personal Protective Equipment; Compliance; Worker.

Cite This Article: Landelinus Humau, Hari Rarindo, and Andreas Umbu Roga. (2018). "THE RELATIONSHIP BETWEEN BEHAVIORAL OF HEALTH WITH THE USED OF PERSONAL PROTECTIVE EQUIPMENT (PPE) IN PT. SARANA AGRA GEMILANG KUPANG EAST NUSA TENGGARA." International Journal of Research Granthaalayah, 6(3), 78-87. https://doi.org/10.29121/granthaalayah.v6.i3.2018.1500. 


\section{Introduction}

Safety working is a systematic effort to keep safety and comfortable working circumstance for labours in particular working area. Nowadays, the problems occurring on safety work issues remain serious focus and attention from many parties. In many examples, unsafety working system is ignored by both labour and working institution themselves. As it is mentioned in our constitution that prosperity and safety work are the main objectives in labour, there have been many efforts to keep these two important points by national development on labour applied in comprehensive and sustainable process.

In carrying on the protection of labours, there was man invested by the production of Labour Act No. 08, 2010 and No. 13, 2003 about safety work. The process of protecting and improving labors' prosperity and safety becomes the main effort in Indonesia which remains the objectives of National Health Program stated by the the government.

Workplace accident is often caused by some circumstances or unsafe condition and human action called unsafe act. Most of researches prove that the dominant affecting factor of accident is unsafe acts (Silalahi, 1995). One of them is to ignore using safety equipment's. By this reason, it is necessary to apply self-protection to each labour that will minimize the risk of workplace accident. PT. Sarana Agra Gemilang, an industrial cement corporation, has potential risks on accidents on work caused by unsafe act. Some researches state that those risks are affected by the personal desire in using safety equipment's during working process. The last report on workplace accident in 2016 stated that there were five cases on work accident covering fail over the spot, struck down, pilled up, and direct contact to dangerous materials. International Labour Organization (ILO) research released that there are 6.000 who die after workplace accidents which takes 15 death roll for a second and 2.2 milion for a year. General Director of Safety Guidance of Labour Ministry, Muji Handoyo, sates that Indonesia is categorized to have high level of death roll data on safety work issue in ASEAN. Muji says that this accurate data was obtained in 2010 when there were 98.000 cases causeing 1.200 death roll. It is quite high comparing to European countries like Germany and Denmark which have more than 100.000 cases with less than 500 death roll. PT. Jamsostek provided data of savety work issue in 2012 with nine death roll a day from 103.000 cases in the year (Roga AU, 2015)

Table 1: Workplace Accident in Sarana Agra Gemilang, Ltd. period 2014-2016

\begin{tabular}{|c|c|c|c|c|c|}
\hline \multirow[t]{2}{*}{ Year } & \multicolumn{4}{|c|}{ Cause } & \multirow[t]{2}{*}{ Total } \\
\hline & Blister & Slipped & Pinned & Fail over & \\
\hline 2014 & 2 & 3 & 3 & 6 & 14 \\
\hline 2015 & 1 & 4 & 4 & 1 & 10 \\
\hline 2016 & 1 & 2 & 8 & 5 & 16 \\
\hline Total & 4 & 9 & 15 & 12 & 40 \\
\hline
\end{tabular}

Those accidents in table (1) are included into minor accident in workplace in period of 20142016 containing four blisters, nine slipped, 15 pinned, and 12 fail over. It is categorized as minor accident because the corporation did not spend high cost on health care and recovery. Besides, those labors only took three days at maximum to rest. 
Table 2: General Characteristics of Labours at Sarana Agra Gemilang, Ltd., 2016

\begin{tabular}{|l|c|c|}
\hline Respondent Characteristic & Amount (n=99) & Percentage (\%) \\
\hline Usia : & & \\
\hline$>20$ year & 63 & 63,6 \\
\hline < 20 year & 36 & 36,4 \\
\hline Working period : & & \\
\hline$>6$ year & 78 & 78,8 \\
\hline$<6$ year & 21 & 21,2 \\
\hline Educational background : & & \\
\hline Elementary & 20 & 20,2 \\
\hline Junior HS & 32 & 32,3 \\
\hline Senior HS & 23 & 23,2 \\
\hline Bachelor Degree & 24 & 24,2 \\
\hline
\end{tabular}

Table (2) above provides information about the dominant respondents of $>20$ years with total persons $63(63.6 \%),<20$ years contains 36 labours $(36,4 \%)$. The working period consists of > 6 years covers 78 persons $(78,8 \%)$ and $<6$ years are 21 labours $(21,2 \%)$.

The dominant labour has Junior HS educational background with 32 people (32,3\%), those who with elementary school background are 20 people (20,2\%), 23 persons with senior HS (23,2\%), 24 bachelors $(24,2 \%)$.

\subsection{Bivariate Analysis}

Bivariate selection was applied doing che-square test between independent and dependent variables. See the following table (3)

Table 3: Relationship between age and subservience of labour at Sarana Agra Gemilang, Ltd., in 2016

\begin{tabular}{|c|c|c|c|c|c|c|}
\hline \multirow[t]{2}{*}{ No. } & \multirow[t]{2}{*}{ Age } & \multicolumn{2}{|c|}{ Subservience Labour } & \multirow[b]{2}{*}{ Total } & \multirow[b]{2}{*}{$\mathbf{R P}$} & \multirow[b]{2}{*}{ P. Value } \\
\hline & & Subservience & unSubservience & & & \\
\hline 1. & $>20$ yo & 36 & 27 & 63 & \multirow{3}{*}{0,86} & \multirow{3}{*}{0,351} \\
\hline 2. & $<20$ yo & 24 & 12 & 36 & & \\
\hline Tot: & & 60 & 39 & 99 & & \\
\hline
\end{tabular}

Basedon table (3) above, it is known that there are variables included into multivariate model with the value of $\mathrm{p}<0,25$ containing working period variable $(\mathrm{p}=0,000)$, knowledge $(\mathrm{p}=0,003)$, safety equipment availability $(\mathrm{p}=0,000)$, and motivation $(\mathrm{p}=0,001)$. Age, attitude, and educational background are not included into multivariate since they have value $p>0,25$.

\subsection{Multivariate Analysis}

There are four variables obtained after doing bivariate selection which are categorized as multivariate model; working period, knowledge, safety equipment availability, and motivation. The results of multivariate analysis of independent to dependent variable are provided in table (4) by applying double logistic regression test. 
Table 4: Variables in the equation

\begin{tabular}{|l|l|l|l|l|l|l|}
\hline \multicolumn{2}{|l|}{} & B & Sig. & $\operatorname{Exp}($ B) $)$ & \multicolumn{2}{|c|}{$\mathbf{9 5 . 0 \%}$ C.I. for EXP(B) } \\
\cline { 6 - 7 } \multicolumn{2}{|c|}{} & & & & Lower & Upper \\
\hline Step 1 & Masa_Kerja & -2.944 & .005 & .053 & .007 & .412 \\
\hline & Constant & 2.893 & .010 & 18.050 & & \\
\hline
\end{tabular}

Table (4) of Variables in The Equation shows that constant value and coefficient value for each variable in column B, p value variable in column Sig. and OR value (Odds Ratio) in Exp (B) column and Lower and Upper values. Thus, there are three important thing to recognize:

1) Risk factor consistently influences in significant way to subservience of labour The consistent risk factor is a variable with $\mathrm{p}<0,05$ value on multivariate analysis, with $(p=0,005)$ working period while inconsistent variable which significantly gives influence does not exist.

2) Independent variable which dominantly influences subservience labours Variable that has the biggest $\mathrm{OR}$ is the most influencing variable to subservience labours. Therefore, table (4) shows that working period is the most influencing variable to subservience labour with the value of OR; 0,053 .

3) Logistic regression model to subservience labours

Table (4) provides that constant $(\alpha)$ is 2.893 . If $\mathrm{X} 1$ is the value of working period, the coefficient value of working period ( $\beta 1)$ should be -2.944 .

\section{Discussion}

\section{Age}

Table (3) in the previous section shows that the dominant respondents are in the average of $>20$ y.o, with 63 peole $(63,6 \%)$ and $<20$ y.o with 36 persons $(36,4 \%)$. Statistical tests (prevalence rate) shows that respondents with the average age of $<20$ y.o, 0,86 un subservience compared to those whoe are $>20$ y.o. this variable does not have significant relationship to the subservience labour in Sarana Agra Gemilang, Ltd, in 2016 with $\mathrm{p}$ value $=0,351$ ( $\mathrm{p}>0,05$ ). It is caused by the average of labours'age which impacts directly to skill mastery and knowledge that lead to the desire to go after regulation regarding safety work.

This research goes along with the previous one done by Felly Philipus Senewe (2011) who found that there was no significant relationship between age and pursuance of using safety equipment's in working with the value of $(\mathrm{p}=0,102)$. The result of this research is similar to Frida Rizki's (2015) who found the same result to the previous.

Age is one of the factors that impacts individual characteristic starting from his childhood and repeat in sustain way. (Elizabeth, 1995 in Barizqi, 2015). According to psychological theory of working development, age is categorized into pre-adult (20-40 y.o), adult (41-65 y.o), and senior (over 65 y.o).

Gilmer (in Hikmawan, 2013) states that there is a relationship between age and working performance and followed by upgrading level of performance which demands physical performance, mental health, skills, and responsibility. Generally, many companies take young prospective labours through recruitment process with the consideration that those prospective 
labours have good and strong physical and mental health, are dynamic, creative, but are less experienced, irresponsible, improper, which impacts their safety in working. In other hand, the old labours, with their less physical performance, are experienced focus, responsible, and trusted. They tend to be safe in working. (Fitriana, 2012).

\section{Working Period}

Table (4) indicates that working period $>6$ years with 78 labours $(78,8 \%)$ and $<6$ year with 21 labours $(21,2 \%)$. The prevalence rate test shows that the respondents with $<6$ years working period are 0,53 un subservience to regulations compared to those who work for $>6$ years. This variable depicts significant relationship to pursuance of regulation in terms of safety work in Sarana Agra Gemilang Ltd, in 2016 with $\mathrm{p}$ value $=0,000(\mathrm{p}<0,05)$. The result reflects the same findings by Himawan's (2013) and Fitriana's (2012) who found that working period affects labour subservience with the value of $\mathrm{p}=0,003$ and $\mathrm{p}=0,000(\mathrm{p}<0,05)$. Working period is a range of time a labour works in particular company. Accoeding to Fitriana (2012), the more working period is the more skill will be achieved that causes the decrease of accidents at workplace. It can be observed in those who longer work in particular company with minimum risks of accident they have compared to the young labours with more accident cases. Experience and skills are affecting those who are safe in working time.

\section{Educational Background}

Table (4) indicates that the dominant respondents are from Junior HS level of education with 32 labours $(32,3 \%)$, elementary education consists of 20 people $(20,2 \%)$, those who completed senior HS level are 23 people $(23,2 \%) 24$ bachelors $(24,2 \%)$. Prevalence rate test shows that those who only completed elementary education are 3,11 un subservience compared to those who completed higher educational level. This variable does not refer significantly to the subservience labours in Sarana Agra Gemilang, Ltd in 2016 seen from the value of $\mathrm{p}$ value = $0,658(\mathrm{p}>0,05)$.

A research done by I Kadek Saputra (2014) and Arifin (2013) found that there is no significant relationship between educational background and subservience labours in using safety equipment's with the value of $\mathrm{p}=1,000$ dan $\mathrm{p}=0,065$. Educational level impacts skills, perspective, willingness in having training, and the way of taking risks in working. Besides, educational level impacts consideration in making decision. It is true that lower educational level causes long time taking in making decision. In contrast, those who are from higher educational level tend to be attractive more specifically in making decision, (Handayani, 2015).

According to (2014), educational level determines the level of awareness in stating safety work. Educational background also influences understanding working environment and job description.

\subsection{Pre-Deposition Factor Influence Toward Subservience Labour}

\section{Competence}

It is known that the dominant respondents who have enough competence are 83 persons $(83,8 \%)$ and those who have less competence are 16 people $(16,2 \%)$. The prevalence rate test indicates that the less competence is 0,58 unpursucnce compared to those who have good competence. 
This variable relates to the significant influence on subservience labours in Sarana Agra Agra Gemilang, ltd., in 2016 with p value $=0,003(\mathrm{p}<0,05)$.

Maharanny's research (2016) on the same topic found there is a meaningful relationship between labour's competence and pursuance in using safety equipment's while working with the value of $\mathrm{p}=0,003(\mathrm{p}<0,05)$. Herianto (2015) also discovered that the same relationship with the value of $\mathrm{p}=0,021(\mathrm{p}<0,05)$. It is caused by the lack of knowledge mastered by the labours in using safety equipment's while working which finally affects the high risks on accidents on workplace in SAG Ltd. Kupang.

Knowledge is the result of human senser input which manifested into performance. Most of knowledge is gained by sight and hearing (Geller, 2001). Knowledge becomes very important in shaping and constructing someone's skills and attitude in working, more specifically on using safety equipment's in order to minimize the risks of workplace accidents. This concept goes along with The Safety Triad theory (Geller, 2001) which take knowledge as former of safety work culture.

The understanding of safety work by using safety equipment's in longer time will cause a culture of safety work. The occurrence of safety work culture begins by maximizing cognitive dominant of labours. It is stated by Baron (2003).

\section{Attitude}

The result of this analysis shows that there are respondents with positive acceptance on safety work issue are 76 persons $(76,8 \%)$ while those who are contrast are 32 labours $(23,2 \%)$. The prevalence rate test indicates that those who are negative are 1,00 more vulnerable or not to obey the regulation than those who are categorized as positive persons. This variable relates significantly to labour pursuance in Sarana Agra Gemilang, Ltd. in 2016 with p value = 0,976 $(p>0,05)$. This is caused by the average attitude of labours are positive to obey the regulation regarding using safety equipment's in working.

A research done by Irene (2013) and Djoenada (2014) who found that attitude affects not significantly to labour pursuance in using safety equipment's with the value of $\mathrm{p}=0,114$ and $\mathrm{p}=0,301(\mathrm{p}>0,05)$. The occurrence of pursuance in using safety equipment's as a culture in work is caused by personal experience of labours themselves in doing their jobs. This is called attitude which gets better day by day. The involvement of emotional feeling in working process also contributes to the development of safety work culture (Wawan \& Dewi, 2011).

Positive attitude towards the use of safety equipment's in work shows that respondents accept and are responsible for their work. The positive attitude tends to make someone to be familiar, friendly, and is responsible for his job.

Newcomb in Notoatmodjo (2010), states that attitude is an awareness and readyness to act and is not a reason of any reaction. Attitude is an action and reaction of previous action. It is called a closed action to stimulation and object around.

Attitude covers three main forming components; cognition, affection, and conatiion. Cognitive component relates to knowledge, perception, believe, and everything that reflects how someone 
percepts certain object. Respondent's positive knowledge regarding the use of safety equipment is a kind of cognitive aspects reflecting positive attitude towards objects around him.

Those who are negative in terms of cognitive aspect tend to ignore obeying the rules concerning awareness of using savety equipments in working. It is caused by the lack of knowledge which is included into cognitive aspect.

\subsection{The Influence of Possibility and Strengthening Factors Toward Labour Pursuence}

\section{The Availability of Safety Equipment's}

Based on the result of this analysis, there were some groups of respondents divided based on the availability of safety equipment's containing those who own 83 persons $(83,8 \%)$ and those who are without equipment's are 16 respondents $(16,2 \%)$. The prevalence rate test indicates that those who are not with safety equipment are 0,53 not to obey the regulation compared to those who are with safety equipment. This variable is significantly related to labour pursuance in Sarana Agra Gemilang Kupang in 2016 with $p$ value $=0,000(\mathrm{p}<0,05)$. The reason is that the availability of safety equipment's in the company is under level of standard. It impacts to the unpusuence to the regulation concerning the use of safety equipment.

This result goes along with a previous research done by Eka (2014) and Diah Sumarna (2013) who found that there is significant impact of safety equipment availability to labour pursuance with the value of $p=0,004$ and $p=0,002$. Equipment's are tools needed and used in particular activities. Safety equipment's are tool provided by company and used by labours in doing particular work in order to cover and minimize the risks in working area including accidents and incidents. The availability of safety equipment is included into probability factor which can be found in the theory of Lawrence Green (Notoatmodjo, 2005). The availability of safety equipment's is a standardized procedure that is a must for a company to provide. In fact, the availability of safety equipment does not guarantee the achievement of safety work at a company.

\section{Motivation}

The result of this research also indicates that respondents with motivation are 85 persons $(85,9 \%)$ while those who do not have specific motivation are 14 people $(14,1 \%)$. The prevalence rate test proves that those who are without motivation are 0,54 unpursuence than those who have right motivation. This variable relates significantly to the use of safety equipment in Sarana Agra Gemilang Kupang in 2016 with $\mathrm{p}$ value $=0,001(\mathrm{p}<0,05)$. It is caused by the lack of motivation of labours in using savety equipment while working. There are many workers think that the use of safety equipment is not necessary. Thus, they ignore using them. This is called motivation.

This research indicates the same conclusion as what has been done by Dwi Okta Rizkiani (2011) and Kartika Dyah (2015) who proved that there is a significant influence of motivation to labour pursuance in using safety equipment with the value of $p=0,024$ and $p=0,018$. According to Bisen and Priya (2010), motivation is psychological process that causes someone act or react on something he thinks to do. It is the reason of someone doing activity to reach particular objectives. 
This research proves that motivation of labours while working determines pursuance in using safety equipment. It goes along with the theory of The Safety Triad (Geller, 2001) which states that motivation has great impact to safety work. Besides, Wijono (2010) distinguishes motivation into; motivation as content; and motivation as process. Motivation as process refers to the efforts in acting or reacting toward object, in terms of safety working.

Labours have perception that if they want to achieve their goals and hope, they have to undergo a process. This leads to a concept of being motivated before doing their jobs. Motivation occurs since there is need, will, and support to achieve the hope and goals. Therefore, how strong a motivation is will determine how far the effort will be.

Mangkunegara (2005) states that the affecting factor of an achievement in working is motivation. A company needs skilled full labours with high motivation on work in order to maximize their potential in working based on their skills. According to Munandar (2001) there is positive relationship between performance and and achievement, meaning that labours with high motivation tend to have good achieve in contrast to those who have low motivation. Suharto and Budhi Cahyo's research (2005) exmined relationship between motivation and labour performance and they found that motivation influences significantly to performance and achievement.

High motivation is needed in terms of reaching goals and targets of a company. Labours will tend to do good work if they have good motivation. In contrast, those who are with low motivation tend to produce mistakes and errors in working. For instance, labour will consider to use or to wear safety equipment when they are well motivated. Besides, they realize that safety equipment are important for them in terms of covering them form accidents and incidents. This motivation has good effect in pursuance of company regulation regarding using savety equipment while working.

\section{Conclusion and Suggestion}

1) The level of pursuance on safety equipment use depends on some factors; age, educational background, period of work, and self-motivation of labour.

2) The pre-deposition factor which affects the use of safety equipment is educational level of labour which influences limited knowledge of the use of safety equipment's and then causes workplace accidents with high risks. Misunderstanding on safety equipment's use is also considered as an affecting factor even though labours understand well about the risks on work.

3) The reinforce factor is monitoring activity on field regarding the use of safety equipment by the labours which is not accordingly applied as the regulation including rewardand punishment to those who are good and ignore using safety equipment's. In this case, company as work and safety equipment providers must be responsible and needs to fulfill all the standardized regulations and availability of safety equipment.

4) The attitude and positive behavior of labours in understanding and using safety equipment needs to improve. The low rate of good attitude becomes one of the reasons of accidents occurring while working. The regulation and benefits of using safety 
equipment must be intensively socialized by the company to the laboring order to minimize risks caused by workplace accidents.

5) The availability of safety equipment must be guaranteed by the company. The socialization on regulations regarding safety work needs to be improved. These procedures will minimize the risks caused by workplace accidents.

\section{References}

[1] Alhamnda, S. Buku Ajar Ilmu Kesehatan Masyarakat. Yogyakarta : Deepublish

[2] Arifin. 2013. Faktor yang Berhubungan Dengan Kejadian Kecelakaan Kerja pada Pekerja PT. Bangunan. Tesis Penelitian

[3] Azwar, S. 2008. Sikap Manusia: Teori dan Pengukurannya. Yogyakarta: Pustaka Pelajar.

[4] Bazirqi, N. 2015. Hubungan Antara Kepatuhan Penggunaan APD dengan Kejadian Kecelakaan Kerja pada Pekerja Bangunan PT. Adhi Karya Tbk Proyek Rumah Sakit Telogorejo Semarang.Universitas Semarang

[5] Buntarto, D. 2015. Panduan Praktis Keselamatan dan Kesehatan Kerja untuk Industri. Yogyakarta : Pustaka Baru Press

[6] Dahlan, 2008. Penyajian Data Epidemiologi Kesehatan. Yogyakarta : Pustaka Baru Press.

[7] Darmawan, A,dkk. 2014. Hubungan Kelengkapan APD, Lama Pembagian Waktu Kerja dan Pemahaman Pekerja tentang Breafing dengan kecelakaan Kerja di Pabrik Kelapa Sawit PT. Bukit Barisan Indah Prima Jambi. Jurnal Kesmas Volume 2, Hal. 18 - 26. Mei 2014.

[8] Depnaker, RI. 2010. Undang-Undang No. 1 tahun 1970 Tentang Keselamatan Kerja.

[9] Depnaker, RI. 2010. Pedoman Pengawasan Penggunaan APD. Jakarta: Direktorat Pengawasan Norma Keselamatan dan Kesehatan Kerja.

[10] Depnakertrans, 2002. Alat Pelindung Diri. Jakarta: Badan Litbang Depnakertrans Pusat Pengembangan Keselamatan Kerja dan Hiperkes.

[11] Dwi, Ria Lestari. 2015. Evaluasi Tingkat Kepatuhan Karyawan terhadap Keamanan Data pada Sisfo Menggunakan COBIT 5 Framework. Palembang : Jurnal Informatika, Universitas Bina Darma Palembang

[12] Fakultas Kesehatan Masyarakat. 2012. Panduan Penyusunan Dan Tata Cara Ujian Skripsi Fakultas Kesehatan Masyarakat Universitas Airlangga Tahun 2011/2012. Surabaya : Airlangga University Press

[13] Felly, S. 2011. Faktor-Faktor yang Mempengaruhi Kepatuhan Pekerja dalam Bekerja. Jurnal Kesehatan

[14] Fitriana. 2012. Faktor yang Mempengaruhi Perilaku Tenaga Kerja Percetakan terhadap Penggunaan APD di Bagian Produksi PT. Antar Surya Jaya Surabaya. Tesis. Surabaya : Universitas Airlangga

[15] Frida, R. 2015. Hubungan Antara Kepatuhan Penggunaan APD dengan Kejadian Kecelakaan Kerja pada Pekerja Bangunan. Tesis Penelitian

[16] Handayani, E. 2015. Hubungan Antara Penggunaan APD, Umur dan Masa Kerja dengan Kecelakaan Kerja pada Pekerja Bagian Rustic di PT. Borneo Melintang Buana Eksport Yogyakarta. Jurnal Kesmas UAD Volume 4, No. 3.

[17] Harrington, J.M. 2003. Buku Saku Kesehatan Kerja. Jakarta : EGC

[18] Herianto. 2015. Faktor-Faktor yang Berhubungan dengan Tingkat Kepatuhan Pekerja dalam Menggunakan APD. Jurnal Kesmas

[19] Hikmawan, M. 2013. Faktor yang Berhubungan Dengan Kejadian Kecelakaan Kerja pada Pekerja Bengkel Pengecatan Mobil di Kota Makasar. Jurnal

[20] Irene. 2013. Pengaruh Pelatihan dan Disiplin Kerja terhadap Para Karyawan Pekerja PT Bangunan. Jurnal Kesmas 
[21] Kadek, I. 2014. Faktor-Faktor yang Berhubungan dengan Kepatuhan Pekerja di Bengkel Las. Jurnal Penelitian

[22] Kartika, D. 2015. Hubungan Tingkat Pengetahuan dan Sikap Pekerja terhadap Kepatuhan Penggunaan APD. Tesis Penelitian Kesehatan

[23] Maharanny. 2016. Faktor yang Berhubungan dengan Kepatuhan Pekerja Terhadap Penggunaan APD di PT. Bangunan. Jurnal Kesehatan

[24] Nawawinetu. 2007. Higiene Perusahaan. Universitas Airlangga. Surabaya

[25] Notoatmodjo, S. 1993. Pengantar Pendidikan Kesehatan dan Ilmu Perilaku Kesehatan. Yogyakarta: Andi Offset.

[26] 2003. Pendidikan dan Perilaku Kesehatan. Jakarta: Rineka Cipta.

[27] 2005. Metodologi Penelitian Kesehatan. Jakarta: Rineka Cipta.

[28] 2007. Promosi Kesehatan dan Ilmu Perilaku. Jakarta: Rineka Cipta.

[29] 2010. Metodologi Penelitian Kesehatan dan Kedokteran. Jakarta: Rineka Cipta.

[30] Perdana, RW. Muliatna, IM, 2014. Pengaruh APD trhadap Keselamatan dan Kesehatan kerja ( K3 ) Karyawan di Bengkel M. Mischan kalijudan Surabaya. Jurnal Kesmas Volume 03, No.2 Tahun 2014.

[31] Putri, D. 2014. Analisis Faktor yang Berhubungan dengan Kepatuhan Menggunakan Alat Pelindung Diri. Jurnal Volume 1, No. 1 Januari-April 2014

[32] Riyanto. 2012. Analisis Data Kesehatan dan Aplikasi Program SPSS. Jakarta : EGC

[33] Roga AU, 2015. Manajemen Sektor Pertanian ( Kajian Pada Petani sawah Desa Sinduharjo, Kecamatan Ngaglik, Kabupaten Sleman, Daerah Istimewa Jogjakarta ). Disertasi, Universitas gajah Mada, Jogjakarta

[34] Saryono. 2011. Penyajian Data Statistik Kesehatan. Jakarta : EGC

*Corresponding author.

E-mail address: glennhumau@ gmail.com 